Research Article,

\title{
Social Determinants of Health among Health Workers in a Tertiary Health Institution in Anambra State, Nigeria: A Pilot Study
}

\author{
Joe-Ikechebelu NN ${ }^{1,2,3}$ Umeh UM, ${ }^{1,2}$ Azuike EC,${ }^{1,2}$ Okechukwu CE, ${ }^{4}$ Akanwa AO,${ }^{2,5}$ Ngene WO, ${ }^{2,6}$ \\ Nwankwo BE ${ }^{7}$
}

${ }^{1}$ Department of Community Medicine and Primary Healthcare, Chukwuemeka Odumegwu Ojukwu

University (COOU) Teaching Hospital (COOUTH), Awka, Anambra State, Nigeria

${ }^{2}$ Nigeria Coalition of Eco-social Health Research (NCEHR), Chukwuemeka Odumegwu Ojukwu University (COOU), Igbariam Campus, Anambra State, Nigeria.

${ }^{3}$ Interdisciplinary Program, Social Dimensions of Health, Public health and Social Policy, Human and Social Development, University of Victoria, British Columbia, Canada.

${ }^{4}$ School of Population and Public Health, Faculty of Medicine, University of British Columbia, Vancouver, British Columbia, Canada.

${ }^{5}$ Department of Environmental Management, Chukwuemeka Odumegwu Ojukwu University, Uli Campus, Anambra State, Nigeria.

${ }^{6}$ Department of Physiotherapy, Chukwuemeka Odumegwu Ojukwu University Teaching Hospital (COOUTH) Awka, Anambra State, Nigeria.

${ }^{7}$ Otorhinolaryngology Unit, Chukwuemeka Odumegwu Ojukwu University Teaching Hospital (COOUTH), Awka, Anambra State, Nigeria.

Email Address: nn.ikechebelu@ coou.edu.ng

\begin{abstract}
:
Background:

Social determinants of health $(\mathrm{SDH})$ are a critical theme for health equality for Nigeria. Nigeria is one of the countries in the world which is far from achieving targets of 2030 SDG 3 due to this inequity in health.
\end{abstract}

\section{Methods:}

This is a cross-sectional pilot survey designed to collect information about the SDH, strengths, challenges and perceived areas to be addressed among different cadres of healthcare workers at the Chukwuemeka Odumegwu Ojukwu University Teaching Hospital (COOUTH) Awka in the South eastern part of Nigeria. This is a cross-sectional pilot survey among the different cadres of healthcare workers.

\section{Results:}

The elements of SDH are vital for the continuing well-being of health workers because of their role in attending to the totality of their community. From our study, two elements of SDH (family and physical activity) had the greatest level of confidence (44\% and $26 \%$ respectively), while the justice system (police and the legal issues) had the lowest areas of confidence ( $2 \%$ each), but the greatest strength of the community were found in education (70\%) and family (58\%).

\section{Conclusions:}

Policies in general need to be implemented to address the economic instability in order to yield positive outcomes towards education, security of lives and property, food security and affordable healthcare and transportation. Reducing health inequities in Nigeria will depend on a focus addressing the social circumstances of individuals, families and communities using equity-based approaches on the broader structural environment. The role of formal and informal educational strategies will be beneficial in the highlighted social, economic and political factors from this study. 
Keywords: Social determinants of health, healthcare workers, Awka, Nigeria

\section{Interoduction:}

The social determinants of health (SDH) are the conditions in which people are born, grow, live, work, and age; are shaped by multilevel distribution of money, power and resources; and are responsible for the unfair and avoidable differences in health status seen in and across countries. ${ }^{(1)}$ Social factors play a relevant role in health, and are the root cause of health disparities $^{(2)}$. Sound health is related to the quality of the environmental factors (e.g., water supply, sanitation facilities, food, and climate), and the interplay of these factors influence the spread of communicable and noncommunicable diseases. ${ }^{(3-5)}$ An effective interaction of the physical environment and other constituents of the SDH are essential to achieve health equity as well as the agenda for sustainable development.

The third 2030 sustainable development goal pledged to ensure healthy lives and to promote well-being for all ${ }^{(6)}$, while the 2011 World Conference on Social Determinants of Health (SDH) in Rio declared that health inequities (e.g., early childhood development, education, employment, housing, physical environment, and access to health services) that arise from societal conditions are unacceptable. ${ }^{(7)}$ Though the SDG Africa Index for Nigeria ranked low at 43 out of 54 African countries, there has been some improvement with some SDG health indicators, even with a population of above 195 million, in the last decade. The life expectancy at birth increased from 49.4 years in 2007 to 54.0 years in 2017, the under-five mortality rate (U5MR) per 1000 live births decreased from 146.3 to 122.1 in the same decade, while the maternal mortality ratio decreased from 1200 in the year 2000 to 917 per 100,000 live births in 2017 , but this is a far cry from achieving the set-out SDGs by 2030 when compared to other countries such as Ghana, Rwanda, Norway, Australia ${ }^{(8-12)}$

The unemployment rate in Nigeria is at $23.1 \%$, and the 2018 World Bank report noted that half of Nigerian population live below the international poverty line (\$2 per day). ${ }^{(13)}$ Food security, has been linked to poor nutrition, which is a risk factor for certain diseases (e.g., diabetes, cancer). ${ }^{(14)}$ Though healthcare may be a weak determinant of health outcome ${ }^{(15,16)}$ but, people face barriers that limit access to health care services daily, with worsening health disparities and lack of universal health coverage that translate to poor access to primary healthcare services worsening direct and indirect costs of healthcare (e.g., transportation fees) ${ }^{(17,18)}$ and often lead to delay and denial of health care services. A recent review of healthsystem financing for Universal Health Coverage in Nigeria showed a high out-of-pocket expenses for health care, a low budget for health at all levels of government, and poor health insurance coverage. ${ }^{(18)}$ Out of the less than $5 \%$ of Nigerians who have health insurance coverage, majority of these enrollees are in the formal sector, with very poor coverage of the informal sector. ${ }^{(18-20)}$ A study conducted in the south-east of Nigeria revealed a high out-of-pocket expenditure on healthcare putting about $24 \%$ of household below poverty line. ${ }^{(21)}$ Education heightens the possibility of being employed with impact on income, healthy behaviors, longevity, setting foundations for healthy lives as seen in a study where the level of education affected access to health services, ${ }^{(22)}$ but the social cohesion seen within families have been noted as the cornerstone on which the society rests. ${ }^{(23)}$

The social determinants of health vary among the six geopolitical regions of Nigeria, and this study serves to highlight the social determinants affecting health, the level of confidence, and the challenges that exist across a sampled health care workers at Chukwuemeka Odumegwu Ojukwu University Teaching Hospital (COOUTH) Awka, Anambra State, Southeast Nigeria. It is important to address the elements of SDH to improve the general health of the people thereby reducing or eliminating the health inequities arising from social and economic problems.

\section{Materials and Methods: \\ Setting}

The setting is Chukwuemeka Odumegwu Ojukwu University Teaching Hospital (COOUTH), a state government-owned tertiary health institution situated at Awka, the capital city of Anambra state, south east of Nigeria. It is a multidisciplinary specialist centre providing clinical, therapeutic, diagnostic as well as preventive health care services to the residents of Awka and its environs as well as the neighboring states of Enugu, Delta, Ebonyi, Abia and Imo. 


\section{Study Design}

This is a descriptive cross-sectional pilot study, which analyzed the social determinants of health among health workers at the COOUTH Awka. The health workers included doctors, nurses, pharmacists, medical laboratory scientists and ward maids. This study was conducted from 7 th April 2019 to 28th June 2019. The questionnaire was pretested and validated with about 8 individuals across Anambra State, Southeast of Nigeria.

\section{Justification of Pilot Study Sample Size}

Based on sample size calculation with population less than 1000, 95\% confidence level, and a 5\% margin of error, the minimum sample size for a later larger study in COOUTH with an average staff population of 700 will be with 249 respondents, and allowing for attrition, will include 312 respondents. ${ }^{(24)}$ This is a pilot study and size estimation with random selection will be a better representation of the population of interest for the larger study. However, to allow for attrition, ${ }^{(25)} 50$ of the respondents who completed and returned their questionnaires were analyzed out of the 60 that were distributed.

\section{Ethical Clearance}

Ethical clearance was obtained from COOUTH Health Research Ethical Committee with a reference

Number

\section{COOUTH/CMAC/ETH.C/VOl.1/FN:04/0028.}

\section{Data Collection}

The instrument of study was a semi-structured interviewer administered questionnaire designed to obtain information on the socio-demographic characteristics of the 50 respondents as well as responses and opinions on the strengths and challenges of the various social determinants of health as they exist in their communities.

\section{Data Analysis}

Data was analyzed using Statistical Package for Social Sciences (SPSS) version 20.1. Frequency distribution and percentages of all relevant variables were generated.

\section{Results:}

A total of 50 respondents were interviewed by the research assistants with the help of the structured questionnaire.

Table1 shows the sociodemographic characteristics of the respondents. The mean age of the respondents is $30.10 \pm 5.2$. Majority $29(58 \%)$ of them were males. Most of the respondents 28 $(56 \%)$ were first degree holders and a good number $17(34 \%)$ were on a monthly household income of a hundred thousand naira and above $(\geq \# 100,000)$. One $(2 \%)$ earned less than ten thousand naira (>\#10,000), and $11(22 \%)$ preferred not to disclose their income.

Table 2 illustrates the varying level of confidence the respondents have for the various areas as they exist in their communities. They showed extreme confidence in family $22(44 \%)$ and basic confidence in education $23(46 \%)$ but no confidence in insurance and police: $48 \%$ and $42 \%$ respectively.

Table 3 shows the responses to the greatest strength of the community. Education (70\%) followed by family (58\%) according to their responses depicts an area of great strength while insurance was the least $8 \%$.

Table 4 shows their responses to the levels of greatest challenges of the community. Their responses showed employment to be the greatest challenges of the community $33(66 \%)$ followed by the police and poor access to healthcare $(64 \%$ and $58 \%$ respectively). Family and lack of community activities were the least with 14 (28\%).

Table 5 illustrates their ranking on the level of need for the various areas as they exist in their communities. In the area of healthcare need, the respondents opined that the need for primary care was greatest 46 (92\%); this was followed by specialty care $(76 \%)$ and eye care (72\%); healthcare need for substance abuse was the least $29(58 \%)$. Their greatest nutritional need was access to affordable healthy foods (64\%). The greatest transportation need was affordability 38 $(76 \%)$, while the need for transportation to healthcare ranked second $(74 \%)$. In the area of substance abuse, according to the responses, $70 \%$ perceived the need for prevention programs in substance abuse while $46 \%$ opined a need for reduction in drug prescription for substance abuse. The need for access to mental health care treatment was high 37 (74\%), followed by provision of preventive mental health programs $35(70 \%)$. The response was low in the area of need for residential mental health treatment $(58 \%)$ compared to the other mental health needs. Affordable housing was top on the list for the housing needs and this was $84 \%$. For greatest employment need, the respondents will need income generating skills 41 $(82 \%)$ while job search and placement assistance was $58 \%$. For their education needs, $78 \%$ of the 

Anambra State, Nigeria: A Pilot Study

respondents were for life training skills and $74 \%$ for health education. A good number of respondents 36 (72\%) need childhood development while few respondents of 17 (34\%) felt the need for parenting class.

Table 1: Socio-demographic characteristics of respondents $(\mathbf{n}=\mathbf{5 0})$

\begin{tabular}{|c|c|c|}
\hline Variables & $\begin{array}{l}\text { Frequency } \\
(\mathbf{n}=\mathbf{5 0})\end{array}$ & $\begin{array}{l}\text { Percentage } \\
(\%)\end{array}$ \\
\hline \multicolumn{3}{|l|}{ Age (in years) } \\
\hline 21 to 25 years & 6 & 12.0 \\
\hline 26 to 30 years & 25 & 50.0 \\
\hline 31 to 35 years & 10 & 20.0 \\
\hline 36 to 40 years & 5 & 10.0 \\
\hline 41 to 45 years & 1 & 2.0 \\
\hline 46 to 50 years & 1 & 2.0 \\
\hline \multicolumn{3}{|l|}{ Mean age $30.10 \pm 5.2$} \\
\hline \multicolumn{3}{|l|}{ Gender } \\
\hline Male & 29 & 58.0 \\
\hline Female & 19 & 38.0 \\
\hline \multicolumn{3}{|l|}{$\begin{array}{l}\text { Highest level of } \\
\text { education }\end{array}$} \\
\hline Bachelor's degree & 28 & 56.0 \\
\hline $\begin{array}{l}\text { High school diploma }\left(\mathrm{O}^{\prime}\right. \\
\text { level WAEC) }\end{array}$ & 1 & 2.0 \\
\hline Other Graduate degrees & 10 & 20.0 \\
\hline Some University & 3 & 6.0 \\
\hline Postgraduate & 3 & 6.0 \\
\hline Prefer not to answer & 3 & 6.0 \\
\hline Other & 1 & 2.0 \\
\hline \multicolumn{3}{|l|}{$\begin{array}{l}\text { Household monthly } \\
\text { income }\end{array}$} \\
\hline Less than NGN10,000 & 1 & 2.0 \\
\hline
\end{tabular}

\begin{tabular}{|l|l|l|}
\hline $\begin{array}{l}\text { NGN10,000 to } \\
\text { NGN29,000 }\end{array}$ & 2 & 4.0 \\
\hline $\begin{array}{l}\text { NGN30,000 to } \\
\text { NGN39,000 }\end{array}$ & 4 & 8.0 \\
\hline $\begin{array}{l}\text { NGN50,000 to } \\
\text { NGN99,000 }\end{array}$ & 14 & 28.0 \\
\hline NGN100,000 or above & 17 & 34.0 \\
\hline Prefer not to answer & 11 & 22.0 \\
\hline Tribe & & \\
\hline Igbo & 45 & 90.0 \\
\hline Others & 5 & 10.0 \\
\hline $\begin{array}{l}\text { Language spoken at } \\
\text { home }\end{array}$ & & \\
\hline Igbo & 32 & 64.0 \\
\hline English language & 3 & 6.0 \\
\hline $\begin{array}{l}\text { Igbo and English } \\
\text { language }\end{array}$ & 11 & 22.0 \\
\hline Others & 4 & 8.0 \\
\hline
\end{tabular}

\section{Discussion:}

This study showed that the respondents have extreme confidence in family 22 (44\%). This goes to show they agree with clinical studies which have demonstrated strong family influences on individual health. According to the study that estimated the health status of families, it concluded that depending on the family configuration, family plays a crucial role in individual health status. ${ }^{(26)}$ Such family effect on health status was generally similar for physical and mental health. About 23 $(46 \%)$ also showed a basic level of confidence in education. This is similar to the study conducted to evaluate the social determinants of health in some communities in south-east of Nigeria, where education (14.1\%) was regarded as the health determinant with the strongest impact on the lives of the community residents. ${ }^{(27)}$ This may imply that they appreciate the role of education to positive health outcomes as well as its role in informing an individual's access to healthcare. ${ }^{(22,28)}$ On the other hand, the study showed that $42 \%$ respondents have no confidence in insurance. The south-east in Nigeria showed that insurance for community 
residents was $(3.5 \%)$ and this was one of the weak parameters to their health status. ${ }^{(27)}$ As at 2015 , less than $5 \%$ of Nigerians had health insurance coverage. ${ }^{(18-20)}$ Invariably, this may reflect their lack of confidence in appeals from health insurance organizations. Low insurance coverage translates to poor health care because the majority of the health spending will be out of pocket and most individuals are unable to cope with the huge expenditure on health. There was also a lack of confidence expressed with the police work (48\%). The criminal justice system of which the police are a major part is synonymous with security of lives and properties. Hence, it would be difficult to live in a state of complete physical, mental and social well-being in an insecure community, even with the presence of health care facilities. ${ }^{(27)}$ It is worrisome that the citizens of a nation express low level of confidence in the system that they entrusted their lives and properties.

Also, from the responses, $33(66 \%)$ agreed that employment was their greatest challenge in the community. Unemployment comes with consequences such as poverty, food insecurity, poor housing, and poor access to health. These social disparities cannot be overlooked if health inequities are to be addressed. The rate of unemployment in Nigeria was at $23.1 \%$ in 2018, with almost half of the people living below the poverty line of less than 2 dollars. ${ }^{(13)}$

The different areas of need from our respondents that demand urgent attention include healthcare, employment, education, transportation, access to affordable healthy foods, and security of lives. To reduce health inequalities in Nigeria, there is a need for a major thrust that complements the development of health care delivery for an effect on social determinants of health. For example, equipping the educational systems especially the technical colleges to help people acquire income generating skills and trades that could reduce unemployment rate, as well as provide income to access intersecting SDH needs. Such poverty alleviation schemes could improve the circumstances in which people live and work. ${ }^{(2)}$ Also, improved housing conditions as well as the quality of infrastructure and an environment void of pollution will enhance and promote physical health. In order to achieve health equity, there is need for job and wealth creation to stabilize the economy, provision of social security schemes at local, state and national level with continuing reinforcement where these safety nets are already in place. Budget allotted to health and healthcare need to increase appreciably as pledged by African Union nations at the Abuja declaration to allocate at least $15 \%$ of the countries' budget to health. ${ }^{(29)}$ Further, there should be an increase in the national health insurance coverage especially for the informal sector that comprises mainly the vulnerable populace to ensure improved access to health and healthcare.

The scientific evidence for social actions, practices, and policies needed in SDH can be achieved through community based participatory research (CBPR) study in Nigeria. A participatory research is an opportunity for community members to work with the academy as interested and equal partners, with distinct assets that will respond to the agreed community challenge(s), to build and strengthen existing capacity using established activities of phased inquiry for an improved and sustained agency of societal equity and knowledge. ${ }^{(28)}$ This study sets the stage for a participatory inquiry that will bring community inputs to the important and complex area on the social determinant of health. Further, there is a need for a collaboration between global south and north researchers to have an informed participatory action inquiry within the principles of global health research. ${ }^{(31,32)}$

Table2: Responses to level of confidence for various areas as they exist in their communities. (Multiple responses set)

\begin{tabular}{|l|l|l|l|l|l|}
\hline Area & No confidence & $\begin{array}{l}\text { Rarely } \\
\text { confident }\end{array}$ & Confident & $\begin{array}{l}\text { Somewhat } \\
\text { confident }\end{array}$ & $\begin{array}{l}\text { Extremely } \\
\text { confident }\end{array}$ \\
\hline & Frequency (\%) & $\begin{array}{l}\text { Frequency } \\
(\%)\end{array}$ & Frequency (\%) & Frequency (\%) & Frequency (\%) \\
\hline Education & $4(8.0)$ & $13(26.0)$ & $23(46.0)$ & $6(12.0)$ & $3(6.0)$ \\
\hline $\begin{array}{l}\text { Employment/Job } \\
\text { skills }\end{array}$ & $8(16.0)$ & $23(46.0)$ & $11(22.0)$ & $3(6.0)$ & $3(6.0)$ \\
\hline
\end{tabular}


Joe-Ikechebelu NN et all. / Social Determinants of Health among Health Workers in a Tertiary Health Institution in Anambra State, Nigeria: A Pilot Study

\begin{tabular}{|l|l|l|l|l|l|}
\hline Healthcare & $3(6.0)$ & $15(30.0)$ & $20(40.0)$ & $7(14.0)$ & $4(8.0)$ \\
\hline Healthy eating & $6(12.0)$ & $18(36.0)$ & $18(36.0)$ & $4(8.0)$ & $3(6.0)$ \\
\hline $\begin{array}{l}\text { Parks/Green } \\
\text { Space }\end{array}$ & $8(16.0)$ & $17(34.0)$ & $17(34.0)$ & $3(6.0)$ & $3(6.0)$ \\
\hline Mental health & $8(16.0)$ & $14(28.0)$ & $22(44.0)$ & $3(6.0)$ & $2(4.0)$ \\
\hline $\begin{array}{l}\text { Community } \\
\text { activities }\end{array}$ & $6(12.0)$ & $14(28.0)$ & $12(24.0)$ & $13(26.0)$ & $4(8.0)$ \\
\hline Police & $21(42.0)$ & $18(36.0)$ & $5(10.0)$ & $2(4.0)$ & $1(2.0)$ \\
\hline Personal space & $5(10.0)$ & $8(16.0)$ & $26(52.0)$ & $7(14.0)$ & $2(4.0)$ \\
\hline Legal issues & $13(26.0)$ & $16(32.0)$ & $16(32.0)$ & $3(6.0)$ & $1(2.0)$ \\
\hline Insurance & $24(48.0)$ & $15(30.0)$ & $6(12.0)$ & $1(2.0)$ & $2(4.0)$ \\
\hline Physical activity & $7(14.0)$ & $6(12.0)$ & $15(30.0)$ & $7(14.0)$ & $13(26.0)$ \\
\hline $\begin{array}{l}\text { Transportation } \\
\text { Workplace safety }\end{array}$ & $5(10.0)$ & $16(32.0)$ & $20(40.0)$ & $3(6.0)$ & $4(8.0)$ \\
\hline Language & $6(12.0)$ & $15(30.0)$ & $19(38.0)$ & $0(0.0)$ & $5(10.0)$ \\
\hline Family & $2(4.0)$ & $11(22.0)$ & $14(28.0)$ & $6(12.0)$ & $12(24.0)$ \\
\hline Substance use & $15(30.0)$ & $2(4.0)$ & $17(34.0)$ & $6(12.0)$ & $22(44.0)$ \\
\hline Housing & $6(12.0)$ & $16(32.0)$ & $10(20.0)$ & $3(6.0)$ & $5(10.0)$ \\
\hline
\end{tabular}

Table3: Respondents' opinion about the greatest strengths of their community (Multiple responses set)

\begin{tabular}{|l|l|l|}
\hline Strength & Frequency & Percentage \\
\hline Education & 35 & 70.0 \\
\hline Employment & 11 & 22.0 \\
\hline Healthcare & 19 & 38.0 \\
\hline Healthy eating & 8 & 16.0 \\
\hline Parks & 4 & 8.0 \\
\hline Community Safety & 18 & 36.0 \\
\hline Community Activity & 17 & 34.0 \\
\hline Police & 6 & 12.0 \\
\hline Personal Space & 17 & 34.0 \\
\hline Insurance & 4 & 8.0 \\
\hline Transportation & 19 & 38.0 \\
\hline
\end{tabular}


Joe-Ikechebelu NN et all. / Social Determinants of Health among Health Workers in a Tertiary Health Institution in Anambra State, Nigeria: A Pilot Study

\begin{tabular}{|l|l|l|}
\hline Workplace Safety & 13 & 26.0 \\
\hline English & 8 & 16.0 \\
\hline Family & 29 & 58.0 \\
\hline $\begin{array}{l}\text { Mental Health Treatment } \\
\text { Access }\end{array}$ & 8 & 16.0 \\
\hline $\begin{array}{l}\text { Substance Abuse } \\
\text { Treatment Access }\end{array}$ & 5 & 10.0 \\
\hline $\begin{array}{l}\text { Affordable Housing } \\
\text { Option }\end{array}$ & 18 & 36.0 \\
\hline
\end{tabular}

Table4: Respondents opinion about the greatest challenges of their community (Multiple responses set)

\begin{tabular}{|c|c|c|}
\hline Weakness & Frequency & Percentage \\
\hline Employment & 33 & 66.0 \\
\hline Healthcare & 23 & 46.0 \\
\hline Poor access to Healthcare & 29 & 58.0 \\
\hline Police & 32 & 64.0 \\
\hline Lack of Personal Space & 15 & 30.0 \\
\hline Insurance & 27 & 54.0 \\
\hline Language skills & 18 & 36.0 \\
\hline Mental Health & 22 & 44.0 \\
\hline Substance Abuse & 26 & 52.0 \\
\hline Transportation & 18 & 36.0 \\
\hline Family & 14 & 28.0 \\
\hline $\begin{array}{l}\text { Lack of Affordable Housing } \\
\text { options }\end{array}$ & 18 & 36.0 \\
\hline Lack of Healthy Food & 19 & 38.0 \\
\hline $\begin{array}{l}\text { Minimal Recreation and Green } \\
\text { Space }\end{array}$ & 15 & 30.0 \\
\hline Community Safety & 21 & 42.0 \\
\hline Lack of Community Activities & 14 & 28.0 \\
\hline Limited Transportation & 16 & 32.0 \\
\hline Legal issues & 24 & 48.0 \\
\hline Job skills & 18 & 36.0 \\
\hline
\end{tabular}


Joe-Ikechebelu NN et all. / Social Determinants of Health among Health Workers in a Tertiary Health Institution in Anambra State, Nigeria: A Pilot Study

\begin{tabular}{|l|l|l|}
\hline Workplace Safety & 22 & 44.0 \\
\hline English & 17 & 34.0 \\
\hline
\end{tabular}

Table5: Respondents' individual ranking of the level of need for various areas as they exist in their communities.

\begin{tabular}{|c|c|c|c|c|}
\hline Area & High & Low & No need & Don't know \\
\hline & $\begin{array}{l}\text { Frequency } \\
(\%)\end{array}$ & Frequency $(\%)$ & $\begin{array}{l}\text { Frequency } \\
(\%)\end{array}$ & $\begin{array}{l}\text { Frequency } \\
(\%)\end{array}$ \\
\hline \multicolumn{5}{|l|}{ Greatest Healthcare need } \\
\hline Need for Primary care & $46(92.0)$ & $3(6.0)$ & $0(0.0)$ & $0(0.0)$ \\
\hline Need for Specialty care & $38(76.0)$ & $6(12.0)$ & $2(4.0)$ & $1(2.0)$ \\
\hline Need for Dental care & $32(64.0)$ & $6(12.0)$ & $5(10.0)$ & $3(6.0)$ \\
\hline Need for Eye care & $36(72.0)$ & $9(18.0)$ & $1(2.0)$ & $1(2.0)$ \\
\hline Need for Substance abuse care & $29(58.0)$ & $10(20.0)$ & $7(14.0)$ & $1(2.0)$ \\
\hline Need for Mental health & $33(66.0)$ & $10(20.0)$ & $1(2.0)$ & $3(6.0)$ \\
\hline $\begin{array}{l}\text { Need for transportation to } \\
\text { healthcare appointments }\end{array}$ & $31(62.0)$ & $14(28.0)$ & $0(0.0)$ & $2(4.0)$ \\
\hline \multicolumn{5}{|l|}{ Greatest nutritional need } \\
\hline $\begin{array}{l}\text { Need for access to affordable } \\
\text { healthy foods }\end{array}$ & $32(64.0)$ & $13(26.0)$ & $1(2.0)$ & $0(0.0)$ \\
\hline $\begin{array}{l}\text { Need for access to healthy } \\
\text { foods in school }\end{array}$ & $30(60.0)$ & $14(28.0)$ & $2(4.0)$ & $1(2.0)$ \\
\hline $\begin{array}{l}\text { Need for access to healthy } \\
\text { foods in stores }\end{array}$ & $28(56.0)$ & $9(18.0)$ & $5(10.0)$ & $3(6.0)$ \\
\hline Need for cooking classes & $9(18.0)$ & $15(30.0)$ & $16(32.0)$ & $4(8.0)$ \\
\hline
\end{tabular}

\section{Conclusion:}

This work reflects the societal circumstances of the Nigerian populace showing areas of social concerns and inequities. The respondents showed extreme confidence in family which is the basic unit of every community, with education being their greatest strength while employment posed the greatest challenge, and this can be linked to the
Individual needs for primary care, access to affordable healthy foods and transportation, as well as income generating skills. It is imperative that the community's needs, observed from this study, be further explored using participatory action research, such as CBPR. Evidence from this exploration could help in formulation of government policies that could be translated into 

Anambra State, Nigeria: A Pilot Study

daily communal actions. Insurance and the police were ranked the lowest in the area of confidence and strength in the community. In essence, this is a community call to implement universal health coverage and an overhaul of the criminal justice system for an effective security of lives and properties. The improvement in these social determinants of health would go a great way to reduce the health inequities. In conclusion, this is a pilot study that has helped to examine the validity of our questionnaire, and will contribute to a multilevel participatory study, and further research on SDH in Nigerian communities that has shown paucity of studies in SDH.

\section{Conflicting interest:}

Authors have declared no conflicting areas of interest.

\section{References:}

[1] World Health Organization. Social determinants of health: About social determinants of health Online: World Health Organization; 2020 [updated 2020; cited 2019 Dec 27]. Available from: https://www.who.int/social_determinants/sd h_definition/en/.

[2] Marmot M, Friel S, Bell R, Houweling TAJ, Taylor S. Closing the gap in a generation: health equity through action on the social determinants of health. The Lancet. 2008;372(9650):1661-9.

[3] Stafford M, Gimeno D, Marmot $M$. Neighbourhood characteristics and trajectories of health functioning: a multilevel prospective analysis. European Journal of Public Health. 2008;18(6):60410.

[4] Adefemi K, Awolaran O, Wuraola C. Social and environmental determinants of malaria in under five children in Nigeria: a review. 2017. 2017;2(4):6.

[5] Kajang Y, Keswet L. Health Challenges in the Present Democratic Era in Nigeria: The Place of Technology. 2016.

[6] United Nations. \#Envision2030: 17 goals to transform the world for persons with disabilities Online: United Nations; [cited 2019 Dec 27]. Available from: https://www.un.org/development/desa/disab ilities/envision2030.html.
[7] World Health Assembly. Social determinants of health: outcome of the World Conference on Social Determinants of Health (Rio de Janeiro, Brazil, October 2011): report by the Secretariat. Geneva: World Health Organization; 2012.

[8] SDG Center for Africa and Sustainable Development Solutions Network. Africa SDG Index and Dashboards Report. Kigali and New York; June 2019.

[9] The World Bank. Population, total Nigeria Online: The World Bank group; 2019 [updated 2019; cited 2019 Dec 29]. Available from: https://data.worldbank.org/indicator/SP.PO P.TOTL.

[10] The World Bank. Mortality rate, under-5 (per 1,000 live births) Nigeria Online: The World Bank Group; 2019 [updated 2019; cited 2019 Dec 29]. Available from: https://data.worldbank.org/indicator/SH.DY N.MORT.

[11] World Health Organization. Maternal mortality in 2000-2017 Nigeria. Online: Internationally comparable MMR estimates by the Maternal Mortality Estimation InterAgency Group (MMEIG), WHO, UNICEF, UNFPA, World Bank Group and the United Nations Population Division; 2019.

[12] The World Bank. Life expectancy at birth, total (years) Nigeria. Online: The World Bank Group; 2019 [updated 2019; cited 2019 Dec 29]. Available from: https://data.worldbank.org/indicator/SP.DY N.LE00.IN.

[13] The World Bank. Nigeria Online: The World Bank Group; 2019 [updated 2019; cited 2019 Dec 29]. Available from: https://data.worldbank.org/country/nigeria.

[14] Oyewole OE, Atinmo T. Nutrition transition and chronic diseases in Nigeria. Proceedings of the Nutrition Society.74 (4):460-5.

[15] Artiga S, Hinton E. Beyond Health Care: The Role of Social Determinants in Promoting Health and Health Equity. Report/Whitepaper. North America / United States, Health; May 10, 2018. 
[16] Alhassan A, Abdulkareem, Abdu M, Musa. Socio-Economic Determinants of Health Status in Nigeria: A Case Study of Ilorin Metropolis. Lafia Journal of Economics and Management Sciences. 2017;2.

[17] Aregbeshola BS. Out-of-pocket payments in Nigeria. The Lancet. 2016;387(10037):2506.

[18] Uzochukwu B, Ughasoro M, Etiaba E, Okwuosa C, Envuladu E, Onwujekwe O. Health care financing in Nigeria: Implications for achieving universal health coverage. Nigerian Journal of Clinical Practice. 2015;18:437.

[19] Olakunde B. Public health care financing in Nigeria: Which way forward? Annals of Nigerian Medicine. 2012;6(1):4-10.

[20] Onoka CA, Hanson K, Hanefeld J. Towards universal coverage: a policy analysis of the development of the National Health Insurance Scheme in Nigeria. Health policy and planning. 2015;30(9):1105-17.

[21] Amakom UE, Uju. Implications of Households Catastrophic Out of Pocket (OOP) Healthcare Spending in Nigeria. Journal of Research in Economics and International Finance (JREIF). 2012; Vol. 1 (5):5.

[22] Nnonyelu N, Nwankwo IU. Social determinants of differential access to health services across five states of southeast Nigeria. European Scientific Journal. 2014.

[23] Ted M. Family as a Social Determinant of Health: Implications for Governments and Institutions to Promote the Health and Well-Being of Families. Healthcare Quarterly. 2010;14(Sp):60-7.

[24] Araoye MO. Research Methodology with statistics for health and social sciences. Ilorin west, Nigeria: Nathadex publishers; 2004

[25] Johanson GA, Brooks GP. Initial scale development: sample size for pilot studies. Educational and psychological measurement. 2010 Jun;70(3):394-400.
[26] Bello CB, Irinoye O, Akpor OA. Health status of families: A comparative study of one-parent and two-parent families in Ondo State, Nigeria. Afr J Prim Health Care Fam Med. 2018;10(1):e1-e8.

[27] Joe-Ikechebelu N, Osuorah CDI, Nwankwo BE, Ngene W, Nwaneli EI. Evaluation of the Social Determinants of Health in Communities across the South-Eastern Region of Nigeria. anatol $\mathrm{j} \mathrm{fm}$. 2020;3(1):10-6.

[28] Office of the Disease Prevention and Health Promotion. Social Determinants of Health Online: U.S. Department of Health and Human Services; 2014 [updated 2020; cited 2020 April 13]. Available from: https://www.healthypeople.gov/2020/topics -objectives/topic/social-determinants-ofhealth.

[29] World Health Organization. The Abuja Declaration: Ten Years On Online: World Health Organization; 2011 [updated 2020; cited 2020 Jan 3]. Available from: https://www.who.int/healthsystems/publicat ions/abuja_declaration/en/.

[30] Minkler M, Garcia AP, Rubin V, Wallerstein N. Community-based participatory research: A strategy for building healthy communities and promoting health through policy change. USA: University of California, Berkeley, School of Public Health; 2012.

[31] Plamondon KM, Bisung E. The CCGHR Principles for Global Health Research: Centering equity in research, knowledge translation, and practice. Social Science \& Medicine. 2019;239:112530.

[32] Canadian Coalition for Global Health Research. CCGHR principles for global health research Online: Canadian Coalition for Global Health Research; 2015 [cited 2020 April 14]. Available from: https://www.ccghr.ca/resources/principlesglobal-health-research/. 